\title{
Metabolic fingerprinting of the Antarctic cyanolichen Leptogium puberulum-associated bacterial community (Western Shore of Admiralty Bay, King George Island, Maritime Antarctica)
}

\author{
Jakub Grzesiak ${ }^{1}$ (D) Aleksandra Woltyńska ${ }^{1} \cdot$ Marek K. Zdanowski $^{1} \cdot$ Dorota Górniak $^{2} \cdot$ Aleksander Świątecki $^{2}$. \\ Maria A. Olech ${ }^{3} \cdot$ Tamara Aleksandrzak-Piekarczyk $^{1}$
}

Received: 16 November 2020 / Accepted: 24 January 2021

(C) The Author(s) 2021

\begin{abstract}
Lichens are presently regarded as stable biotopes, small ecosystems providing a safe haven for the development of a diverse and numerous microbiome. In this study, we conducted a functional diversity assessment of the microbial community residing on the surface and within the thalli of Leptogium puberulum, a eurytopic cyanolichen endemic to Antarctica, employing the widely used Biolog EcoPlates which test the catabolism of 31 carbon compounds in a colorimetric respiration assay. Lichen thalli occupying moraine ridges of differing age within a proglacial chronosequence, as well as those growing in sites of contrasting nutrient concentrations, were procured from the diverse landscape of the western shore of Admiralty Bay in Maritime Antarctica. The L. puberulum bacterial community catabolized photobiont- (glucose-containing carbohydrates) and mycobiont-specific carbon compounds (D-Mannitol). The bacteria also had the ability to process degradation products of lichen thalli components (Dcellobiose and $\mathrm{N}$-acetyl-D-glucosamine). Lichen thalli growth site characteristics had an impact on metabolic diversity and respiration intensity of the bacterial communities. While high nutrient contents in lichen specimens from "young" proglacial locations and in those from nitrogen enriched sites stimulated bacterial catabolic activity, in old proglacial locations and in nutrient-lacking sites, a metabolic activity restriction was apparent, presumably due to lichen-specific microbial control mechanisms.
\end{abstract}

Keywords EcoPlates $\cdot$ Microbiome $\cdot$ Symbiosis $\cdot$ Metabolism $\cdot$ Bacteria $\cdot$ Lichens

\section{Introduction}

The term Linnaeus used in 1775 to describe lichens was "poor trash of vegetation;" however, this could not be further from the truth [1]. Lichens are exemplary in showcasing symbiosis between their two main components: a mycobiont and a photobiont [2-4]. These organisms

Jakub Grzesiak

jgrzesiak@ibb.waw.pl

1 Institute of Biochemistry and Biophysics, Polish Academy of Sciences, Pawińskiego 5A, 02-106 Warszawa, Poland

2 Department of Microbiology and Mycology, University of Warmia and Mazury in Olsztyn, Oczapowskiego 1a, 10-719 Olsztyn, Poland

3 Institute of Botany, Jagiellonian University, Gronostajowa 3, 30-387 Krakow, Poland associate into easily recognizable and species-specific structures - the vegetative thalli [2]. They thrive in almost all terrestrial habitats on Earth, covering up to $8 \%$ of land surface [1], and are among the first to colonize extreme habitats and newly exposed land [5]. Lichens are more successful in cold habitats than vascular plants; thus, the terrestrial vegetation of ice-free regions of Maritime and Continental Antarctica is dominated by them [6].

Studies on Antarctic lichens revealed their vast distribution, as well as their strict requirements for particular environmental conditions [7]. It has been concluded that nitrogen is a major factor governing the growth of lichens, with species occurrence being strongly linked to nutrient gradients, caused mainly by old and contemporary penguin nesting sites $[6,8]$. According to nitrogen compound concentration preference, lichen species can be: nitrophilous (thriving in nutrient rich sites, irrespective of other environmental variables), nitrogensensitive (avoiding high nitrogen concentrations) or nitrogen- 
tolerant (growing regardless of nitrogen compound concentrations) $[9,10]$. Furthermore, lichens actively participate in primary succession following deglaciation events, ever so accelerating due to global warming [11]. Along with bryophytes, lichens are considered key organisms in the development of the Antarctic terrestrial ecosystem [10].

Non-photobiont prokaryotes, frequently observed on the surface and within the lichen thalli, have been dismissed as functionally irrelevant or even environmental contaminants. However, the dawn of molecular microbiology techniques has led to a recognition of lichen thalli as stable biotopes, small ecosystems providing a safe haven for the development of a diverse and numerous bacteriocenosis [12]. Lichen-hosted bacterial communities have been investigated in numerous lichen species, yet there are no comprehensive studies on if, and how they change, depending on nutrient content preference of the host lichen, as well as the thalli situation within a proglacial chronosequence.

To elucidate if such changes really do occur, we investigated the microbiome associated with the Antarctic lichen Leptogium puberulum Hue, a bipartite, foliose lichen, with Nostoc cyanobacteria serving as its photobiont. Like all lichen cyanobionts, Nostoc cells are located in the lichen thalli extracellularly and possess nitrogen-fixing capabilities [2], making the lichen largely independent of external labile nitrogen sources. This lichen species resides both in nutrient-rich habitats surrounding penguin rookeries, as well as in nutrientlacking areas $[10,13]$. Maritime Antarctica, especially the western shore of Admiralty Bay, presents an excellent site for this type of research. On this relatively small area, sites experiencing high inputs of organic matter (marine bird nesting sites) border those with very limited nutrient content (glacier forefields and dry valleys) [14]. Therefore, these naturally forming trophic and spatio-temporal gradients (glacier foreland chronosequences) have been explored in this paper as study sites.

The main aim of this investigation was to assess carbon compound utilization patterns of the L. puberulum associated bacterial community in relation to lichen thalli habitat "age," along with the exposure of its growth habitat to varying nutrient amounts. Our working hypothesis is that thalli situation within the diverse landscape of the study site has a profound impact on the lichen-hosted microbiome, which is reflected in its carbon source utilization abilities, in terms of diversity and intensity. We thus conducted a functional diversity assessment of the bacterial community residing on the surface and within the thalli of L. puberulum, employing the widely used Biolog EcoPlates, to shed some light on the mechanisms shaping the lichen-hosted bacterial communities in relation to its ecological niche. This is the first paper to tackle the topic of microbial metabolic activity in Antarctic lichens.

\section{Materials and Methods}

The samples were obtained during the $43^{\text {rd }}$ Expedition to the Polish Antarctic Station "Arctowski" in late February/early March of 2019 from ice-free areas along the western shore of Admiralty Bay (King George Island, Antarctica), as well as the barren terrains that border the Southern shore of the Ezcurra Inlet [10]. Lichen specimen samples were collected into sterile containers with sterile tweezers and scissors in triplicate from each sampling site.

\section{Lichen Sampling Scheme}

Samples of the Antarctic eurytopic cyanolichen L. puberulum were collected at four points within a transect on the foreland of the receding Ecology Glacier (King George Island, Maritime Antarctica). This "spatio-temporal gradient" reflected the recession of Ecology Glacier [15-17]. A transect was established that ran across lateral moraines. The first sampling point (L1) was the "youngest" site (time since exposure from beneath glacial ice), where $L$. puberulum growth was apparent. The time since exposure from beneath the ice was circa 20-30 years between sampling points (Table 1). The last sampling point (L4) was established on a ridge of a Neoglacial moraine that has been ice-free for at least 100 years. L. puberulum samples were also collected from two locations varying in nutrient availability. The nutrient-lacking area of Jardine Peak (Southern shore of the Ezcurra Inlet) and the nutrient-abundant area near the Point Thomas penguin rookery were chosen as sampling sites to accommodate the "trophic gradient." For comparative reasons, samples of the ornithocoprophilous/nitrophilous green algae-containing Antarctic lichen Gondwania regalis (Vain.) Søchting, Frödén, and Arup (former Caloplaca regalis (Vain.) Zahlbr.) were collected from the nutrient-abundant area near the Point Thomas penguin rookery. The samples were transported within one hour to the Polish Antarctic Station "Arctowski" and processed at the field laboratory. Taxonomic identification of lichen specimens was done by Maria A. Olech.

\section{External Microbial Fraction Isolation from the Lichen Thallus}

The lichen thalli were briefly rinsed with sterile water to rid them of soil and dust. $0.2 \mathrm{~g}$ of the rinsed thallus was placed in a $50 \mathrm{~mL}$ centrifuge tube containing $20 \mathrm{~mL}$ of extraction fluid (per $100 \mathrm{~mL}$ : $2.4 \mathrm{~g}$ mannitol, $3 \mathrm{~g}$ sorbitol, $0.05 \mathrm{~g}$ cysteine, $0.05 \mathrm{~g}$ ascorbic acid, $1 \mu \mathrm{l}$ Tween $80,0.17 \mathrm{~g} \mathrm{Na}_{4} \mathrm{P}_{2} \mathrm{O}_{7} \times 10$ $\mathrm{H}_{2} \mathrm{O}$ ) and incubated for $30 \mathrm{~min}$ at $4^{\circ} \mathrm{C}$. The samples were then shaken for $1 \mathrm{~h}$ in a Tornado ${ }^{\mathrm{TM}}$ Vortexer at $1000 \mathrm{rpm}$ at $4{ }^{\circ} \mathrm{C}$, then placed in a VWR Ultrasonic Cleaner USC-TH filled with chilled water and sonicated for $5 \mathrm{~min}$ and shortly vortexed afterwards. The extract was filtered into a new $50 \mathrm{~mL}$ 
Table 1 Sampling site description

Sampling site Site description

Approximate sampling site age Coordinates

(time since deglaciation)

\begin{tabular}{|c|c|c|c|}
\hline \multicolumn{4}{|c|}{ Spatio-temporal gradient } \\
\hline L1 & $\begin{array}{l}\text { Ecology Glacier foreland; contemporary lateral moraine ridge; mostly } \\
\text { stones and gravel; very sparse vegetation; isolated colonies of Leptogium } \\
\text { puberulum and Sanionia uncinata (moss), Colobanthus quitensis seedlings; } \\
\text { single specimens of Usnea antarctica on stones }\end{array}$ & 39 years & $\begin{array}{l}62^{\circ} 10^{\prime} 00.6 \\
58^{\circ} 28^{\prime} 07.3\end{array}$ \\
\hline L2 & $\begin{array}{l}\text { Ecology Glacier foreland; contemporary lateral moraine ridge; mostly } \\
\text { loose stones and gravel, sparse vegetation, large colonies of Leptogium } \\
\text { puberulum, isolated small colonies of Colobanthus quitensis and Deschampsia } \\
\text { antarctica, larger isolated specimens of Usnea antarctica }\end{array}$ & 46 years & $\begin{array}{l}62^{\circ} 09^{\prime} 58.7 \\
58^{\circ} 28^{\prime} 05.7\end{array}$ \\
\hline L3 & $\begin{array}{l}\text { Ecology Glacier foreland; neoglacial lateral moraine ridge; gravel semi-bound by } \\
\text { vegetation, loose community made up of Leptogium puberulum, Usnea antarctica, } \\
\text { Deschampsia antarctica and several species of mosses }\end{array}$ & 65 years & $\begin{array}{l}62^{\circ} 09^{\prime} 57.4 \\
58^{\circ} 27^{\prime} 59.1\end{array}$ \\
\hline L4 & $\begin{array}{l}\text { Ecology Glacier foreland; neoglacial lateral moraine ridge; ground mostly covered by } \\
\text { vegetation: Leptogium puberulum, Deschampsia antarctica, Usnea antarctica and } \\
\text { other chlorolichen and moss species }\end{array}$ & $>100$ years & $\begin{array}{l}62^{\circ} 09^{\prime} 56.4 \\
58^{\circ} 27^{\prime} 58.8\end{array}$ \\
\hline \multicolumn{4}{|c|}{ Trophic gradient } \\
\hline LP & $\begin{array}{l}\text { Point Thomas Penguin Rookery; flat planes covered with decaying penguin excreta and } \\
\text { weathered basaltic rocks of varying height occupied by nitrophilous lichens }\end{array}$ & N/A & $\begin{array}{l}62^{\circ} 09^{\prime} 47.8 \\
58^{\circ} 27^{\prime} 32.5\end{array}$ \\
\hline CR & (Leptogium puberelum, Xanthoria spp., Caloplaca spp. and others & N/A & $\begin{array}{l}62^{\circ} 09^{\prime} 48.1 \\
58^{\circ} 27^{\prime} 36.8\end{array}$ \\
\hline LJ & $\begin{array}{l}\text { Jardine Peak area; mostly loose rocks and gravel; large colonies of Leptogium } \\
\text { puberulum, nitrophobic lichen communities on neighboring rock walls (Usnea } \\
\text { aurantiaco-atra, Himantormia lugubris) }\end{array}$ & N/A & $\begin{array}{l}62^{\circ} 09^{\prime} 57.4 \\
58^{\circ} 28^{\prime} 13.3\end{array}$ \\
\hline
\end{tabular}

Spatio-temporal gradient - sampling site at the Ecology Glacier forefield across lateral moraines where the distance from the glaciers edge can be substituted for the time since deglaciation. Trophic gradient - sampling sites of varying nutrient concentrations (Point Thomas Penguin Rookery - high nutrient conc.; Jardine Peak area - low nutrient conc.)

centrifuge tube using a sterile cell strainer with a $70 \mu \mathrm{m}$ mesh. The resulting suspension was used to inoculate the Biolog EcoPlates (Biolog Inc., Hayward, CA).

\section{Internal Microbial Fraction Isolation from the Lichen Thallus}

The washed lichen thallus was cut into little pieces on a sterile Petri dish using a sterile scalpel and transferred into a sterile mortar, to which $3 \mathrm{~mL}$ of extraction fluid was added, as well as $0.5 \mathrm{~g}$ of sterile, sharp, garnet sand (Lysing Matrix A, MP Biomedicals). The samples were delicately ground using a sterile pestle until they had a uniform consistency and were transferred into a $50 \mathrm{~mL}$ centrifuge tube containing $17 \mathrm{~mL}$ of extraction fluid. The samples were then shaken for $30 \mathrm{~min}$ in a Tornado $^{\mathrm{TM}}$ Vortexer at $1000 \mathrm{rpm}$ at $4{ }^{\circ} \mathrm{C}$, then placed in a VWR Ultrasonic Cleaner USC-TH filled with chilled water and sonicated for $5 \mathrm{~min}$ and shortly vortexed afterwards. To separate the extract, the material was centrifuged (60 s, $\left.1000 \mathrm{RPM}, 4{ }^{\circ} \mathrm{C}\right)$. Ten milliliters of the upper supernatant fraction was transferred into a $15 \mathrm{~mL}$ centrifuge tube. The resulting suspension was used to inoculate the Biolog EcoPlates.

\section{Phenotype Fingerprinting with Biolog EcoPlate ${ }^{T m}$}

Lichen-associated bacterial suspensions were centrifuged at $6000 \mathrm{rpm}$ for $5 \mathrm{~min}$ at $4{ }^{\circ} \mathrm{C}$, suspended in sterile, cool $0.9 \%$ saline supplemented with nystatin (final concentration $50 \mu \mathrm{g}$ / $\mathrm{mL}$ ) to prevent fungal metabolism, and adjusted with sterile $0.9 \%$ saline to the optical transmittance of 0.9 . One hundred microliters aliquots of each suspension were added to each well of EcoPlate microtiter plates. EcoPlates contain 3 repeated sets of 31 carbon sources and employ a tetrazolium redox dye as an indicator of microbial metabolism. As microbes utilize the carbon sources, they respire and the tetrazolium reporter dye is reduced to form a visible purple color. Communities of microorganisms will exhibit a characteristic reaction pattern, a metabolic fingerprint that reflects the metabolic properties of the community. One plate (which contains 3 replicates) has been used per suspension (42 plates were used in total). The plates were incubated in darkness at $4{ }^{\circ} \mathrm{C}$, with the color development measured in an OmniLog microplate reader (Biolog Inc., Hayward, CA). Cellular respiration was measured kinetically by determining the colorimetric reduction of the tetrazolium dye. Data were collected approximately twice a week over a 65 day period. The Biolog EcoPlate assays assess the ability of a mixed microbial community to utilize any of the 31 carbon compounds as the sole 
carbon source (plus a single control well without a carbon source). Microbial communities were characterized by their ability to catabolize 10 different carbohydrates, 9 carboxylic and acetic acids, 4 polymers, 6 amino acids, and 2 amines [18]. Data from the $42^{\text {nd }}$ day of incubation was used, as there was no further color development after this date. The final absorbance was first blanked against the "zero" reading time and then blanked against the respective control well without a carbon source. Obtained colorimetric measurement values are given as Omnilog Arbitrary Units (OAU).

\section{Data Analysis}

All results were compiled using Excel (MS Office) 2016 for Windows. Data visualization and statistical analysis have been performed using the $\mathrm{R}$ software ( $\mathrm{R}$ version 4.0.2) and the following packages: ggplot2, fmsb, Hmisc, corrplot, and autoplot.

\section{Results}

Carbon source utilization of the cyanolichen L. puberulum associated bacterial community was assessed on the Biolog EcoPlate tetrazolium salt reduction assay. Sample identities were as follows: L, L. puberulum; CR, G. regalis; E, external community; I, internal community; L1-L4, L. puberulum samples from the Ecology Glacier foreland; P, L. puberulum samples from the Point Thomas penguin rookery; and J, L. puberulum samples from the Jardine Peak area.

OAU values were in the range of $0.00-233.67$. The number of responses at a cut-off value of $\geq 50 \mathrm{OAU}$ (regarded as positive responses) was the highest in samples: L2E (av. 26.0 1.00 ) responses), LIP (av. 24.33 \pm 2.31 responses), LEP (av. 20.33 \pm 2.08 responses), and L2I (av. $22.67 \pm 1.15$ responses). The lowest positive response numbers were obtained in samples: L4E and L4I (av. $4.67 \pm 0.58$ and av. $2.67 \pm 1.15$ responses respectively). Similar values of positive response numbers were achieved in samples: L1E (av. 10.33 \pm 5.69), L1I (av. 8.33 \pm 3.79 ), L3E (av. 11.67 \pm 4.93 ), L3I (av. 10.00 \pm 1.41 ), LEJ (av. 9.67 \pm 8.08 ), and LIJ (av. 9.33 \pm 8.50 ). Strong responses $(\geq 150 \mathrm{OAU})$ were seen to dominate in samples L2E (av. 12.00 \pm 2.65 responses) and LIP (av. $11 \pm 1.73$ responses) (Fig. 1).

Carbon sources utilized by the L. puberulum and G. regalis (added for comparison) associated bacterial communities belonged mostly to the carbohydrate related group: $\alpha$-D-lactose (av. 164.6 OAU), D-cellobiose (av. 158.6 OAU), $N$-acetyl-D-glucosamine (av. 123.2 OAU), $\alpha$-cyclodextrin (av. 129.5 OAU), D-Mannitol (av. 126.4 OAU), and glycogen (av. 103.4 OAU), as well as amino acids: L-asparagine (av. 92.6 OAU), L-arginine (av. 104.2 OAU) (Fig. 2).

The differences between the communities were apparent, as shown by the discrepancies in the utilization efficiency of several carbon sources (Fig. 3). Considerably high values within the same carbon source were obtained for the following samples: L1I (glucose-1-phosphate - 64.8 OAU), L2E ( $\alpha$-ketobutyric acid - 82.4 OAU, D-xylose-174 OAU, L-phenylalanine-195.5 OAU), L2I (L-phenylalanine-193.3 OAU, L-serine-167.4 OAU, glycyl-L-glutamic acid-120.9 OAU, D-galacturonic acid - 151.6 OAU), L3I ( $\beta$-methyl-D-glucoside -176.6 OAU), LIP (4-hydroxy benzoic acid -122.2 OAU, phenylethylamine - 121.6 OAU, D-xylose-185.9 OAU, L-threonine168.22 OAU, D-malic acid-101.2 OAU), CRE (Tween 40$175 \mathrm{OAU}$ ), and CRI (pyruvic acid methyl ester-128.6 OAU, Tween 80-147.7 OAU, $\gamma$-hydroxybutyric acid-160.6 OAU, D-galactonic acid $\gamma$-Lactone - 139.2 OAU). Unusually low efficiency, or even no utilization at all within the same carbon source, was noted in the following samples: L4E (DMannitol-0.0 OAU, $\alpha$-cyclodextrin-5.4 OAU), L4I (DMannitol-0.0 OAU, $\alpha$-cyclodextrin-0.0 OAU, $\alpha$-D-lactose - 9.7 OAU), LIJ ( $N$-acetyl-D-glucosamine-16.7 OAU, Dcellobiose - 1.0 OAU), and CRE (glycyl-L-glutamic acid-16.8 OAU, D-cellobiose-16.8 OAU).

Carbon source utilization patterns of the external and internal bacterial communities overlapped in most cases within samples from a particular site (Fig. 4). Some discrepancies can be seen in the sample duo (external/internal) L1, where the external community had a higher affinity for metabolizing $\beta$-methylD-glucoside (106.92 vs $0.78 \mathrm{OAU}), \gamma$-hydroxybutyric acid (71.82 vs $0.00 \mathrm{OAU}$ ), and L-asparagine (92.48 vs $0.00 \mathrm{OAU}$ ), whereas the internal community preferred glycogen ( 31.55 vs 161.07 OAU). In sample duo L2, the external community exceeded over the internal in the utilization intensity of $\beta$-methyl-D-glucoside (153.08 vs 99.48 OAU) and i-erythritol (150.19 vs $0.00 \mathrm{OAU}$ ), whereas in L3, glycogen ( 97.29 vs $47.56 \mathrm{OAU}$ ) and Tween 80 (94.81 vs $0.00 \mathrm{OAU}$ ) were utilized more efficiently by the external community. In sample L4, $\alpha$-D-lactose was utilized more efficiently by the external community $(95.7$ vs 9.67 OAU). In sample LP, several carbon sources were more intensely oxidized by the internal community, most notably $\alpha$ D-lactose (124.59 vs 218.00 OAU), D-cellobiose (145.11 vs 211.52 OAU), glycogen (139.48 vs $172.37 \mathrm{OAU})$, L-threonine (79.26 vs $168.22 \mathrm{OAU}), \alpha$-cyclodextrin $(157.74$ vs 207.85 OAU), L-phenylalanine (29.70 vs 140.07 OAU), and ierythritol (174.37 vs 225.22 OAU).

Correlations between carbon source utilization intensity based on the Pearson's correlation coefficient were all positive (Fig. 5). The strongest correlations observed with the statistical significance of $p<0.01$ were between the following carbon sources: 4-hydroxy benzoic acid and L-threonine $(r=0.98)$, L-asparagine and Dglucosaminic acid $(r=0.96)$, L-asparagine and putrescine $(r=0.95)$, D-xylose and L-threonine $(r=0.94)$, Dxylose and 4-hydroxy benzoic acid $(r=0.93)$, L-serine and putrescine $(r=0.93)$, L-asparagine and L-serine $(r=$ $0.93)$, and D-xylose and putrescine $(r=0.92)$. 

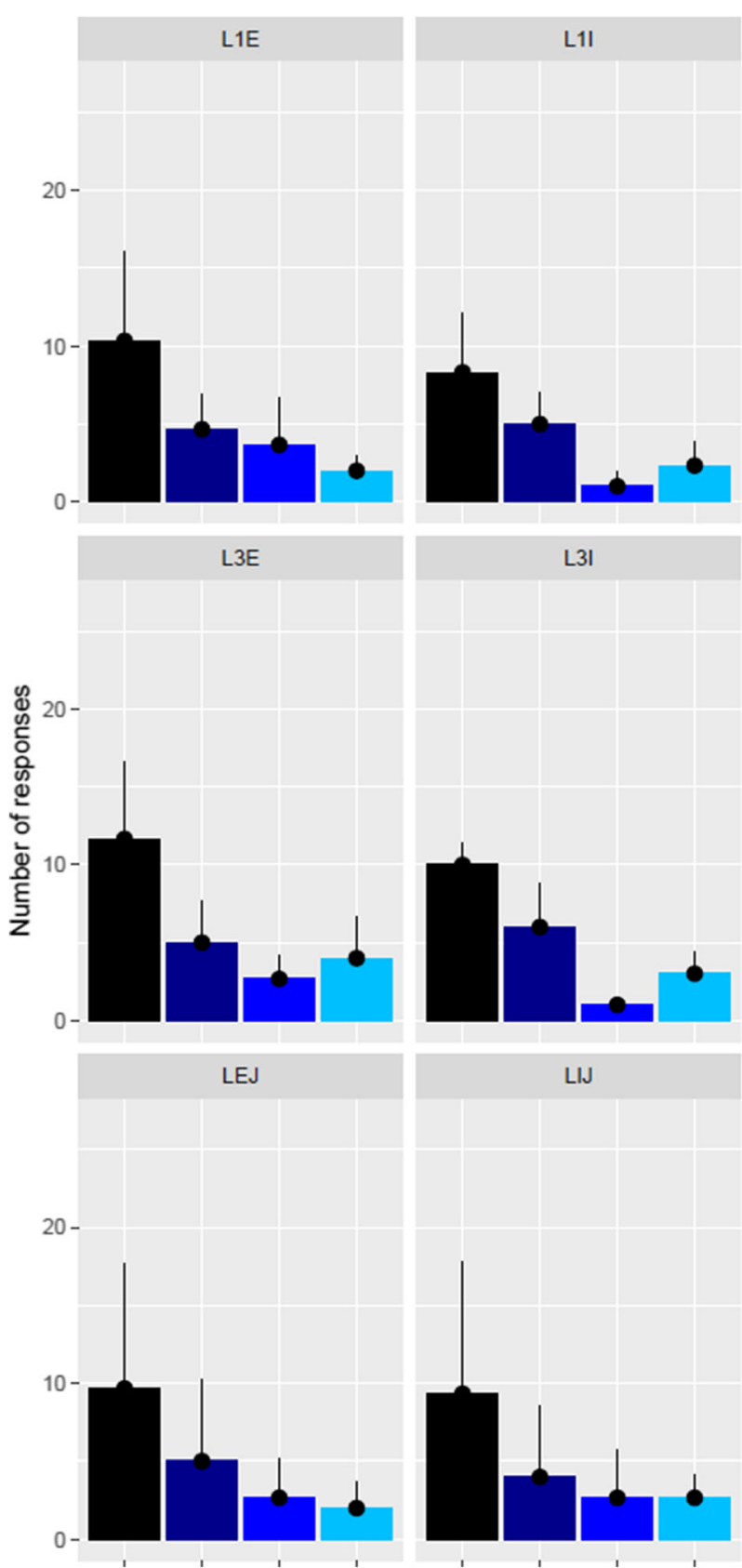

Fig. 1 Response numbers of Leptogium puberulum associated bacterial community based on the Biolog EcoPlate carbon source utilization colorimetric assay coupled with tetrazolium salt reduction. E, external community; I, internal community; L1-L4, Leptogium puberulum samples of the Ecology Glacier foreland; P, Leptogium puberulum samples of Point Thomas penguin rookery; J, Leptogium puberulum

Principal component analysis (PCA) highlighted four distinct groups within the samples (Fig. 6). The closest clustering was revealed between the communities of samples LEJ and LIJ. Clustering was also apparent between samples L1E, L3E, L3I, and L1I. Samples L4E and L4I formed a separate cluster. Loosely clustered samples LEP, L2I, LIP, and L2E formed the fourth group.
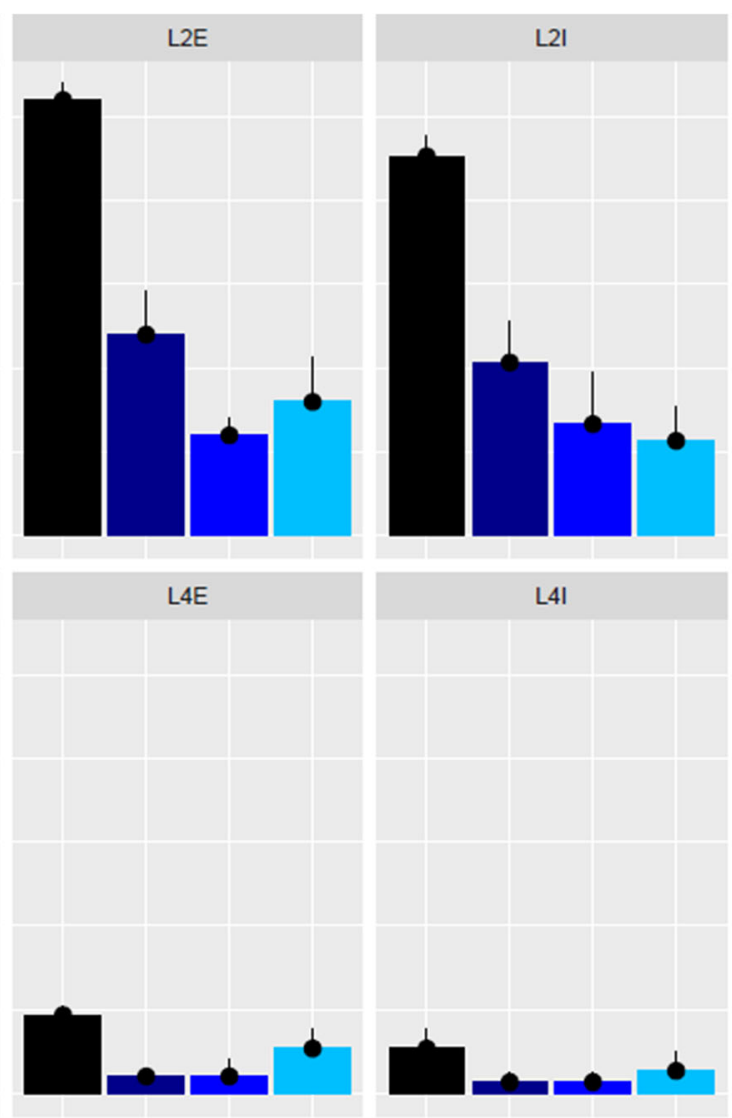

Response
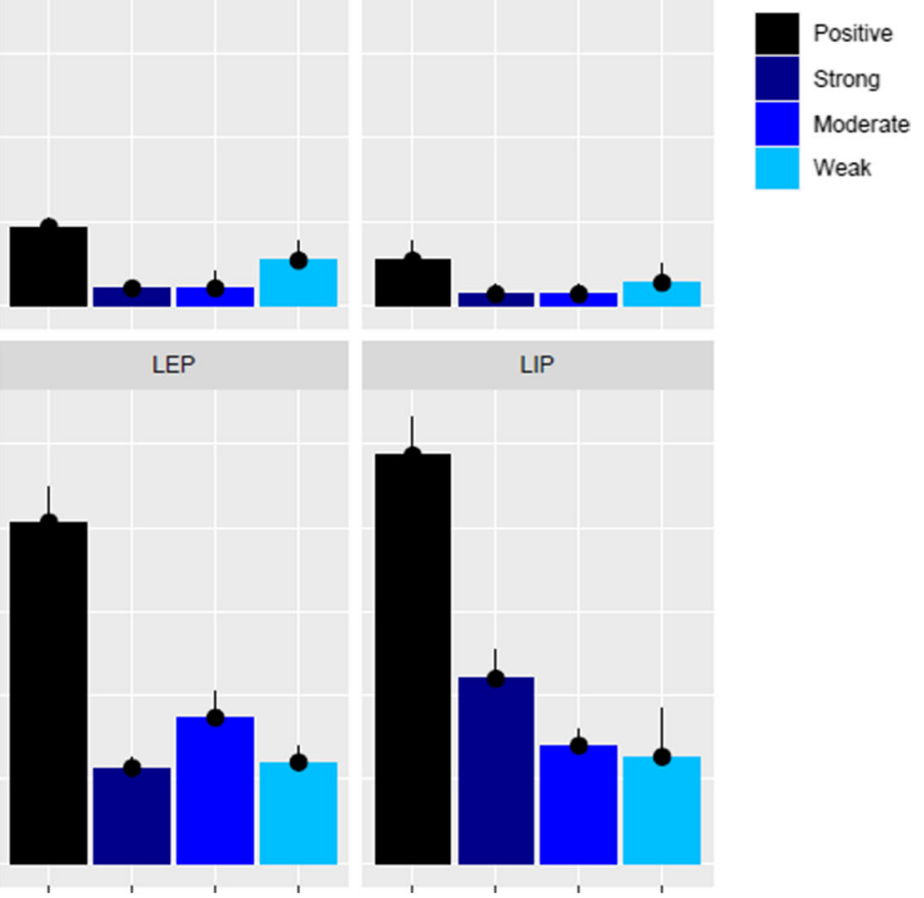

LIP

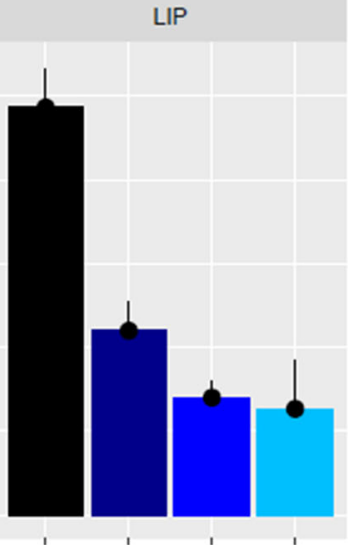

samples of Jardine Peak area. Positive, colorimetric response $>50$ Omnilog Arbitrary Units; strong, colorimetric response $>150$ Omnilog Arbitrary Units; moderate, colorimetric response $=100-150$ Omnilog Arbitrary Units; weak, colorimetric response $=50-100$ Omnilog Arbitrary Units

\section{Discussion}

Community-level physiological profiling using Biolog EcoPlates is based on the premise that carbon source diversity of the microbial habitat shapes the catabolic characteristics of the resident bacterial community [19-21]. Substance exchange between the photobiont and the mycobiont is thought to occur largely through specialized hyphae called haustoria, 


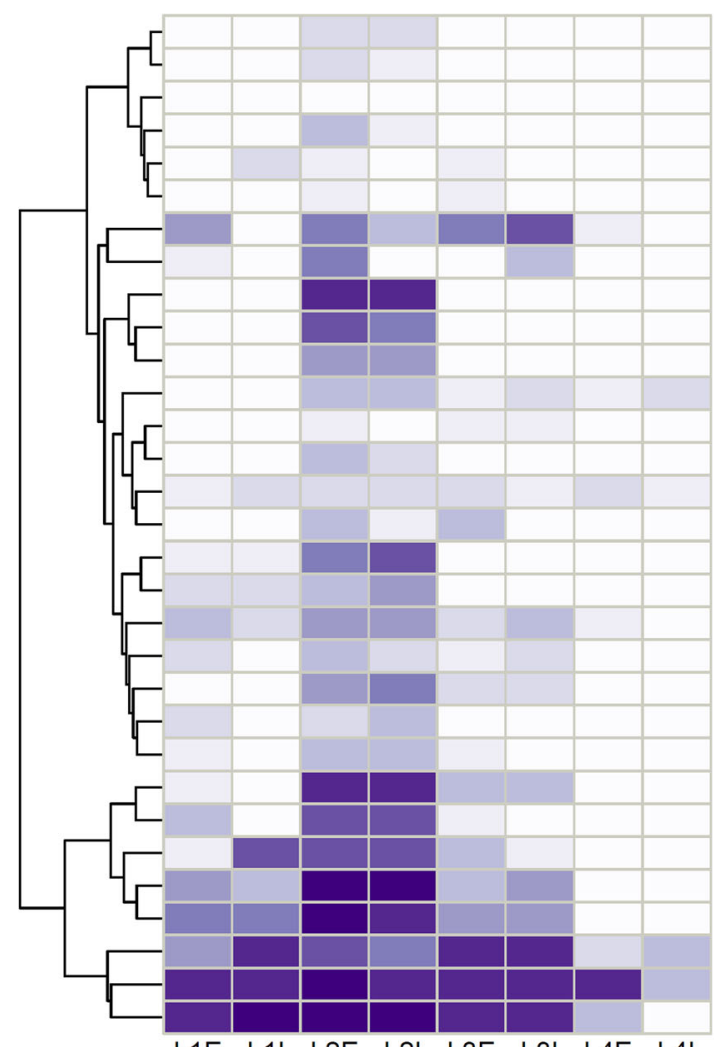

L1E L1। L2E L2I L3E L3I L4E L4I

Fig. 2 Heatmap displaying Leptogium puberulum bacterial community responses on Biolog EcoPlates. Color saturation represents carbon source metabolism intensity. Scale given in Omnilog Arbitrary Units. L, bacterial community of Leptogium puberulum; CR, bacterial

which engulf the cells and bind directly to their cell wall [22]. Data provided in this study, as well as in a paper regarding temperate forest lichens' bacterial community [23], indicate that a substantial portion of the photosynthesized metabolites may be excreted to the extracellular spaces within the lichen (apoplast) and even outside the thallus boundaries, thus shaping the affected bacterial community. The main photosynthesis product provided to the mycobiont in cyanolichens is DGlucose [24]. Due to this, the bacterial community associated with the interior and the exterior of the cyanolichen L. puberulum catabolized mostly compounds belonging to the carbohydrate group, along with amino acids. Glucosecontaining compounds ( $\alpha$-D-lactose, D-cellobiose, glycogen, and $\alpha$-cyclodextrin) were among the most efficiently metabolized. Furthermore, the sugar alcohol D-Mannitol was also readily catabolized. D-Mannitol was proven to be the main energy-storing compound produced from the acquired photosynthate by lichenized fungi [25]. Seemingly, D-Mannitol was also being released into extracellular lichen spaces, although not necessarily as a nutrient (the photobiont does not metabolize D-Mannitol), [26] but presumably as a compatible solute, a protective measure against desiccation and/or freezing events $[25,27]$. Judging by the EcoPlate responses, amino acids may have also been excreted in sufficiently high

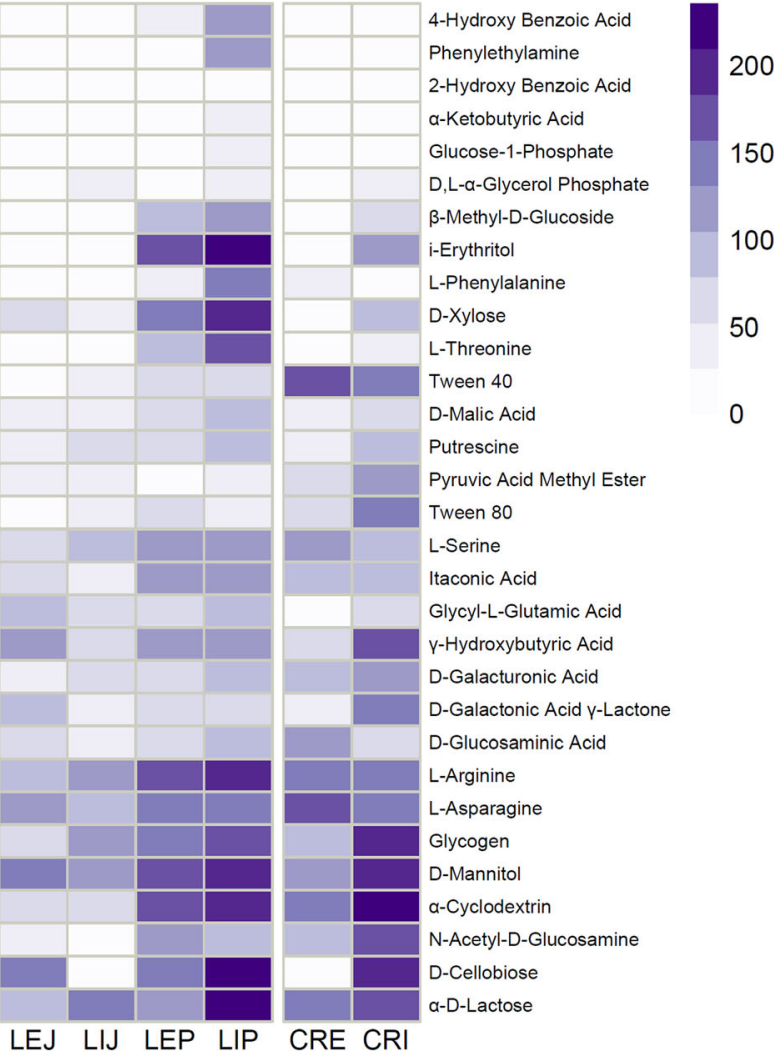

community of Caloplaca regalis; E, external community; I, internal community; L1-L4, Leptogium puberulum samples of the Ecology Glacier foreland; P, Leptogium puberulum samples of Point Thomas penguin rookery; J, Leptogium puberulum samples of Jardine Peak area

concentrations by the nitrogen-fixing cyanobiont, to be successfully assimilated and oxidized by the bacterial community. D-Mannitol consumption abilities significantly correlated with amino acid utilization intensity. The L. puberulum bacterial community may therefore harbor a portion of species exhibiting a scavenging lifestyle that get enriched in numbers during nutrient surpluses. Some studies also indicate that lichen-associated bacteria can actively degrade lichen thalli components like cellulose and chitin [28]. In this respect, the L. puberulum bacterial community expressed D-cellobiose (cellulose derivative) and $\mathrm{N}$-acetyl-D-glucosamine (chitin derivative) catabolism, hinting towards their participation in the degradation of the hosts structural components [29]. Utilization of these two sources did not correlate significantly with catabolism of any other compound, pointing towards them as being an innate trait of the lichen associated microbial community, largely independent from the metabolic status of the lichen thalli. The metabolic traits of the chlorolichen $G$. regalis bacterial community were quite similar to the L. puberulum community. Despite ribitol being the main export product in Trebouxia-containing chlorolichens [30], glucose-bearing compound metabolism was still featured. Some studies indicated that even in those lichens glucose concentrations can be very high, although the underlying 


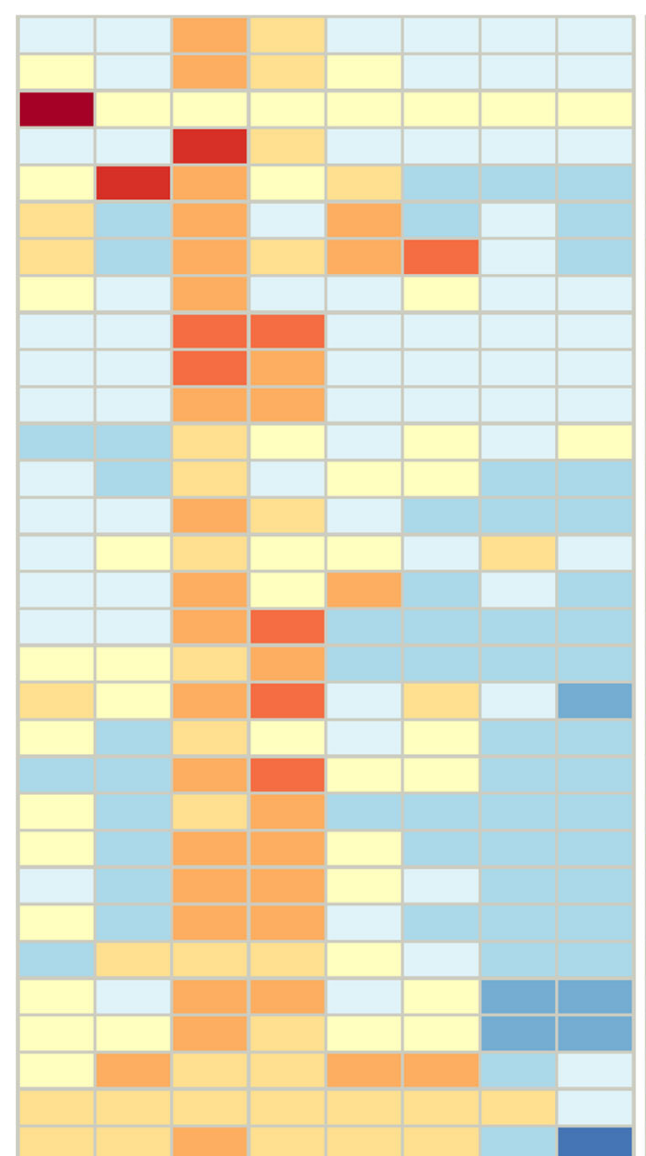

L1E L1I L2E L2I L3E L3I L4E L4I

Fig. 3 Heatmap displaying Leptogium puberulum bacterial community responses on Biolog EcoPlates. Scaling done within rows, indicating the highest and the lowest values across all samples within a particular carbon source. L, bacterial community of Leptogium puberulum; CR, bacterial

mechanism was not explored in detail [31]. However, the most striking feature of the G. regalis bacterial community was the very efficient catabolism of fatty acid-containing compounds like Tween40/Tween80. In support of this, lipid droplets and lipid-like substances have been observed in the G. regalis ultrastructure collected from the same site [32].

Bacterial metabolic trait changes were also investigated in specimens of $L$. puberulum gathered at the Ecology Glacier forefield across lateral moraines, making up a chronosequence [33], where the distance from the glaciers edge can be substituted for the time since deglaciation. This sampling variant was termed the spatio-temporal gradient. Severe differences in terms of the number of utilized carbon sources, as well as utilization intensity, were apparent in the sampling material. In L. puberulum samples procured from the "youngest" site, the bacterial community displayed moderate metabolic diversity on Biolog EcoPlates. This diversity peaked in samples from the neighboring, older site and diminished gradually in samples from sites even further away from the glaciers edge. Considering the dependence of the bacterial community on lichen-derived metabolites [23], this could be explained by

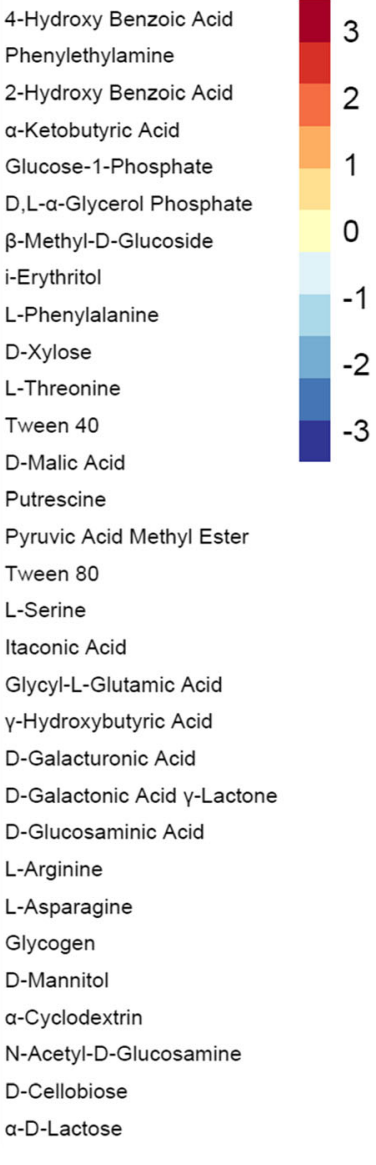

community of Caloplaca regalis; E, external community; I, internal community; L1-L4, Leptogium puberulum samples of the Ecology Glacier foreland; P, Leptogium puberulum samples of Point Thomas penguin rookery; J, Leptogium puberulum samples of Jardine Peak area

the physiological status of the lichen symbiosis, which is strongly connected to lichen development [34]. Several studies on lichen ontogenesis have proposed a scenario of the development of foliose lichens. It was stated that the thallus is mostly active in the marginal, young lobes, while the core remains relatively inert [35]. This is mainly due to the activity of the photobiont, which is dictated by the size, numbers and most importantly, by the age of its cells. Young, small, and numerous cells exhibit high rates of photosynthesis, whereas those of a certain age contribute little to the lichens carbon budget [36]. Therefore, the proportions of the "active" to the "inactive" parts of the thallus can be reflected in the metabolic activity of the bacterial community. Autophototrophs are known to exudate photosynthesis products throughout their cell envelopes when photosynthesis rates are high, in order to: preserve the osmotic and redox potentials of the cell, keep the $\mathrm{CO}_{2}$ assimilation going and, in the case of cyanobacteria, the fixation of nitrogen progressing [37]. Consequently, when the amounts and the diversity of the exuded nutrients increases, the bacterial community is enriched in $r$ strategists, displaying high rates of respiration and a wide compound 

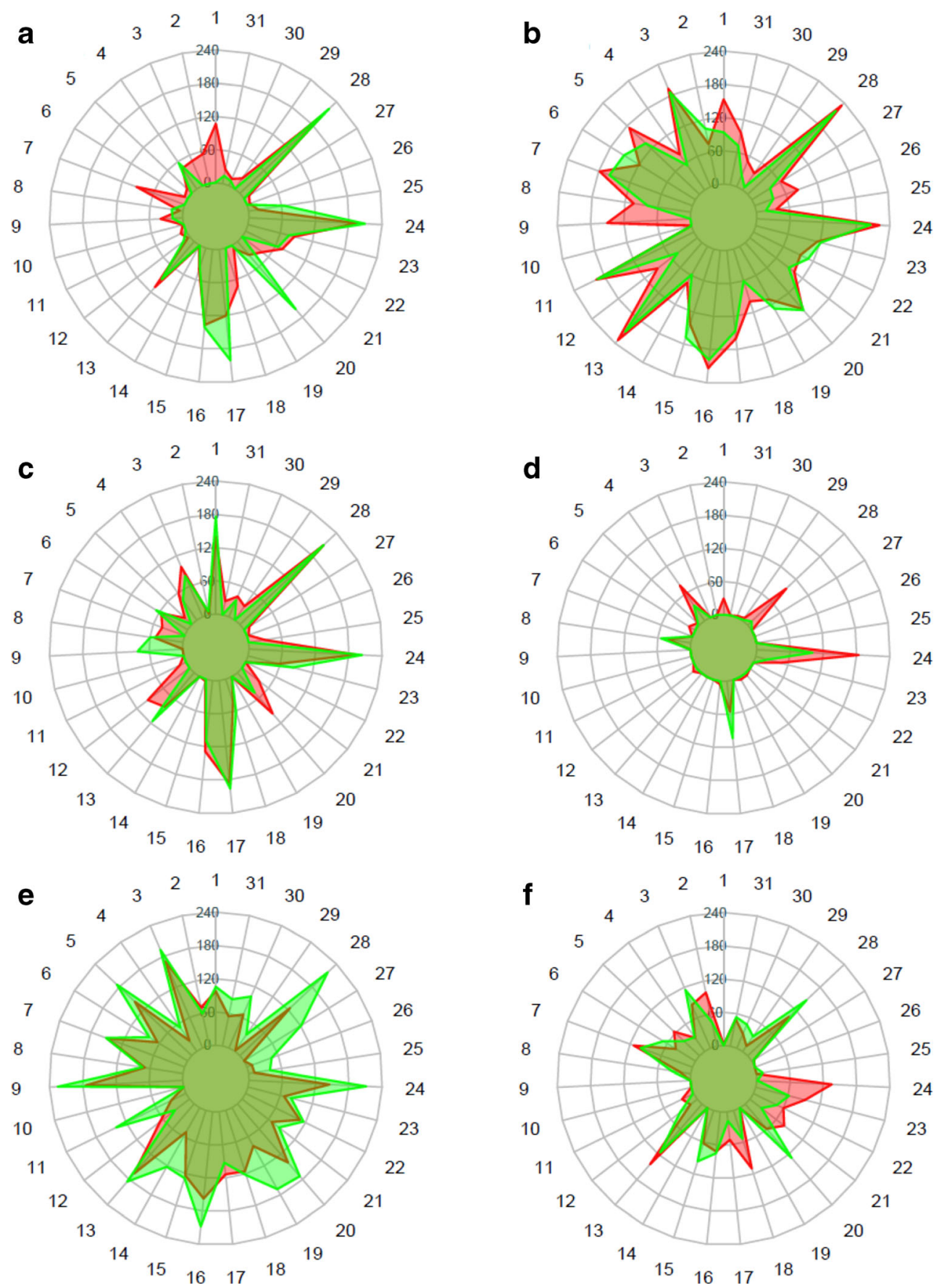

Fig. 4 Radar charts of Leptogium puberulum bacterial community responses on Biolog EcoPlates. External community responses, red; internal community responses, green. a Leptogium puberulum bacterial community responses in sample L1 (Ecology Glacier foreland, closest to glacier terminus); b Leptogium puberulum bacterial community responses in sample L2 (Ecology Glacier foreland), c Leptogium puberulum bacterial community responses in sample L3 (Ecology Glacier foreland), d Leptogium puberulum bacterial community responses in sample L4 (Ecology Glacier foreland, farthest from the glacier terminus), e Leptogium puberulum bacterial community responses in sample LP (Point Thomas penguin rookery), f Leptogium

puberulum bacterial community responses in sample LJ (Jardine Peak area). Scale given in Omnilog Arbitrary Units. 1, $\beta$-methyl-D-glucoside; 2, D -galactonic acid $\gamma$-lactone; 3, L-arginine; 4, pyruvic acid methyl ester; 5, D-xylose; 6, D-galacturonic acid; 7, L-asparagine; 8, Tween 40; 9, ierythritol; 10, 2-hydroxy benzoic acid; 11, L-phenylalanine; 12, Tween 80; 13, D-Mannitol; 14, 4-hydroxy benzoic acid; 15, L-serine; 16, $\alpha$ cyclodextrin; 17, $\mathrm{N}$-acetyl-D-glucosamine; $18, \gamma$-hydroxybutyric acid; 19, L-threonine; 20, glycogen; 21, D-glucosaminic acid; 22, itaconic acid; 23, glycyl-L-glutamic acid; 24, D-cellobiose; 25, glucose-1-phosphate; 26, $\alpha$-ketobutyric acid; 27, phenylethylamine; 28, $\alpha$-D-lactose; 29, D,L$\alpha$-glycerol phosphate; 30, D-malic acid; 31, putrescine 


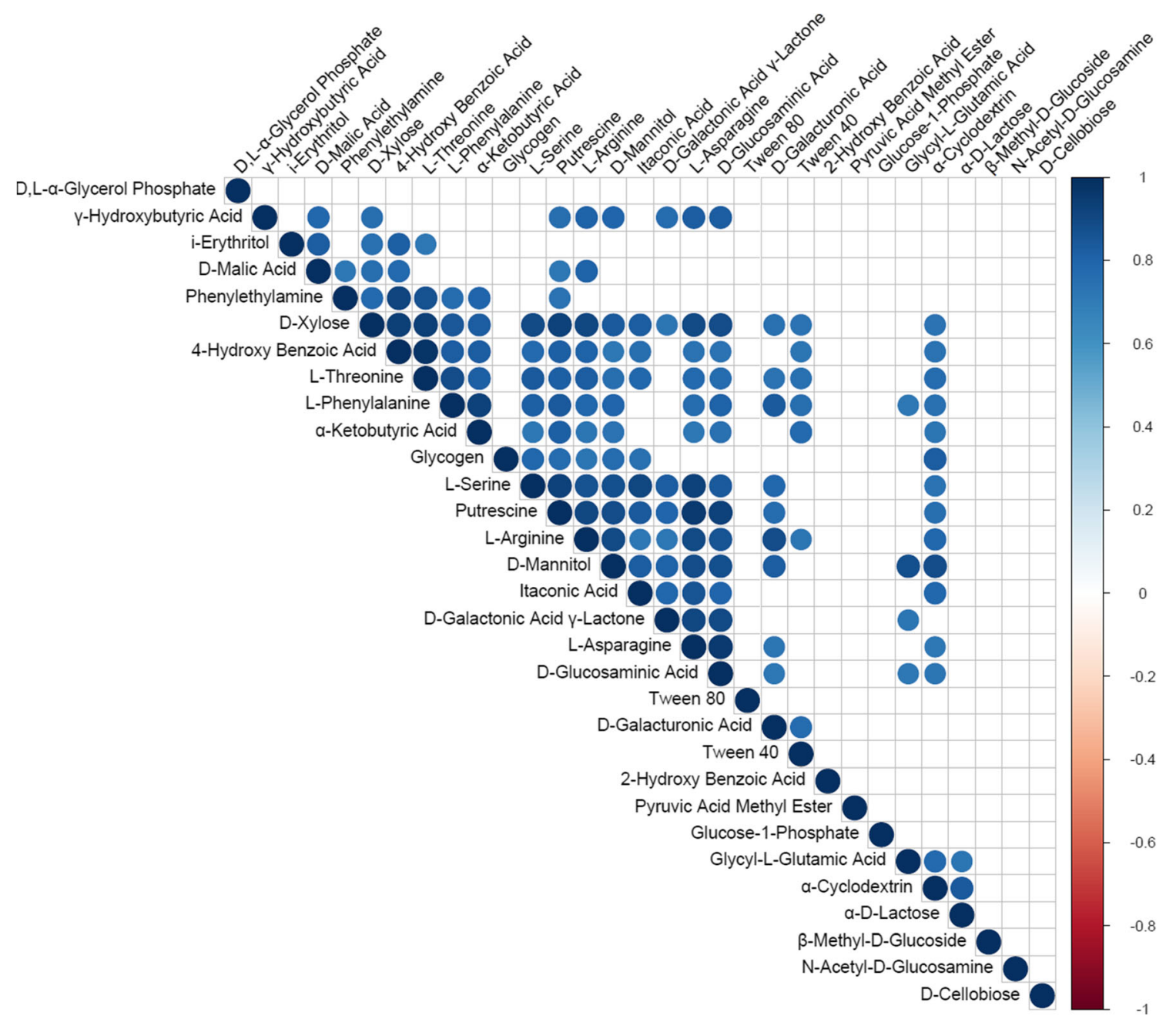

Fig. 5 Correlogram of Leptogium puberulum bacterial community responses on Biolog EcoPlates. Only significant correlations are shown $(p \leq 0.01)$

assimilation ability [38]. The later decline in metabolic trait numbers can therefore be attributed to the lower output of the ageing photobiont. However, the very low activity of the microbiome in the late stages of $L$. puberulum development is somewhat intriguing. This is the stage, where competition from other plant species is very pronounced [39]. Therefore, the lichen might actively control its resident bacteria to diminish the stripping of essential nutrients and to increase its own competitive value. This could be achieved by means of antimicrobial secondary metabolites [40]. Although cyanolichens usually do not produce such compounds [41], this and other studies merit further research [42]. Indeed, the D-Mannitol and glucose-bearing compound catabolism was largely restricted at this stage, while the consumption of cellulose and chitin digestion derivatives was still active. Some researchers proclaim that bacteria in old lichens degrade the thallus for the benefit of the symbiosis, and that the older parts of this metaorganism get recycled [28].

To assess the influence of nitrogen compound concentration in the lichens' growth habitat on the catabolic traits of its associated microbiota, specimens of the nitrotolerant L. puberulum cyanolichen were collected from sites that profoundly differed in imported labile nitrogen levels, namely, an Adelie penguin nesting site (Point Thomas rookery) and a remote highland plato (Jardine Peak area), where external nutrients are deposited in a limited degree [10]. Lichens growing in the immediate proximity to penguin nesting sites experience labile nitrogen influx via the so-called ammonia shadow-ammonia vapors from the ammonification process of the penguin guano [43]. Metabolic traits of the bacterial community from this area involved catabolism of amino acids and other nitrogenbearing compounds. A fertilization experiment published in 2003 indicated that high levels of ammonia are converted in N-tolerant lichens into amino acids, mostly Larginine, to decrease its toxic effects [44]. Moreover, high levels of photobiont derived carbohydrate-like compounds were detected in these fertilized lichens. This could explain the high diversity of metabolic traits, as well as/ together with high respiration rates in the samples from 
Fig. 6 Principal components analysis of Leptogium puberulum bacterial community responses on Biolog EcoPlates. E, external community; I, internal community; L1-L4, Leptogium puberulum samples of the Ecology Glacier foreland; P, Leptogium puberulum samples of Point Thomas penguin rookery; $\mathrm{J}$, Leptogium puberulum samples of Jardine Peak area

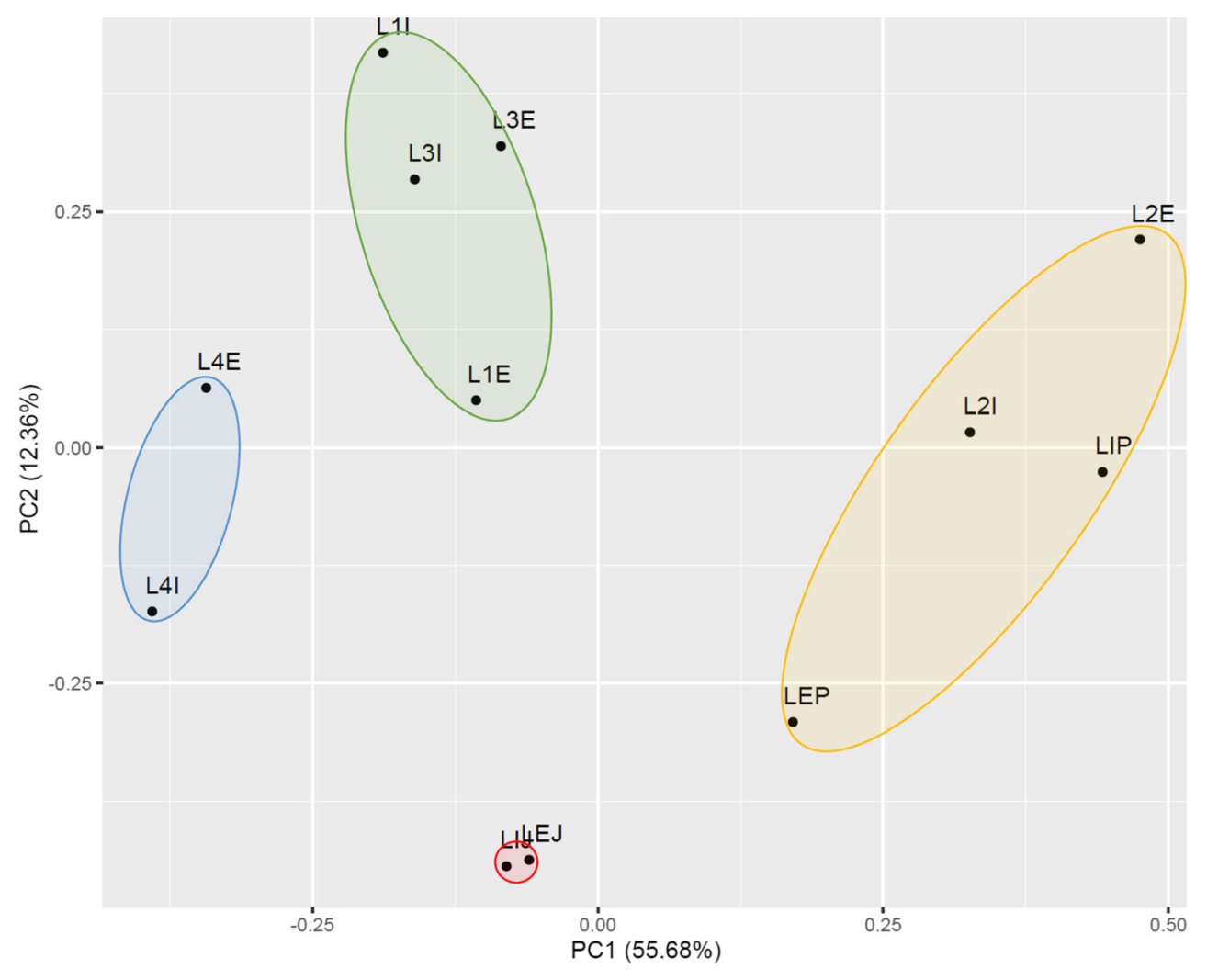

the penguin rookery, as high nutrient levels promote highly active $r$ strategist proliferation [38], similarly as in highly active samples from the Ecology Glacier foreland, as indicated by the PCA clustering. Additionally, D-malic acid catabolism was very active in the rookery samples. D-malic acid, being a metabolite of the Krebs cycle [45], is also useful in leaching biogenic elements from the substratum [46]. Presumably, nutrients like phosphorus and biometals are among limiting factors in such environmental settings [47]. While sequestering these elements, the lichen also provides an easily palatable carbon source for bacteria [48]. L. puberulum growing in the nutrientrestricted area of Jardine Peak harbored a community with a moderate catabolic diversity. An interesting feature in those samples was the suppression of D-cellobiose and $\mathrm{N}$ acetyl-D-glucosamine catabolism. This points towards the lack of thalli degradation processes, presumably due to the necessity of maintaining its integrity. In Antarctic settings, having an intact thallus with a large surface area could mean more efficient water and nutrient (dust, sea spray) acquisition, thus possessing better chances in interspecies competition [49]. However, in such oligotrophic conditions, the thallus seems like an easy target for bacterial degradation by resident and soil bacteria [50]. Consequently, preventing thalli destruction may require antimicrobial metabolite secretion [51], which also affects the external microbial community, as highlighted by PCA clustering, presumably to hinder secondary colonization.

\section{Conclusions}

In conclusion, metabolic traits of the $L$. puberulum associated bacteria sampled at the diverse landscape of the western shore of the Admiralty Bay region (King George Island, Antarctica) displayed substantial differences between sampling sites. In general, the L. puberulum bacterial community catabolized photobiont- and mycobiont-specific carbon compounds like glucose-containing carbohydrates $(\alpha$-D-lactose, D-cellobiose, glycogen and $\alpha$-cyclodextrin) and DMannitol. The bacteria also had the ability to process lichen thalli component degradation products (D-cellobiose and $\mathrm{N}$ acetyl-D-glucosamine). It was apparent that in situations where lichen metabolism was adjuvated, presumably due to increased photobiont output or external "fertilization," the bacterial community responded in increased metabolic diversity and respiration intensity. In specimens from older proglacial sites, or in those growing in nutrient-limited conditions, the opposite was the case. Some metabolic traits, like labile carbon-source scavenging or features connected to thalli degradation, were lacking, presumably constricted by the lichen itself (via antimicrobial compound secretion), due 
to survival/competition related issues. Such phenomena brand the environment-lichen-microbiome interactions as highly complex and worth further attention of multidisciplinary research teams.

Author Contribution Funding acquisition: J.G., M.K.Z, and A.Ś.; conceptualization: J.G., D.G., M.K.Z., A.Ś., and M.A.O.; sampling: J.G., D.G., and M.K.Z.; laboratory analysis: J.G., A.W., D.G., and T.A.P.; data analysis and visualization: J.G.; manuscript preparation: J.G. and A.W.; review and editing: D.G., M.K.Z., M.A.O., A.W., and T.A.P.; responsibility for overall content: J.G.

Funding This research was funded by the National Science Center, Poland (Grant 2017/25/B/NZ8/01915). Samples and data were obtained due to the scientific facility of the Polish Antarctic Station ARCTOWSKI.

Data Availability Upon request

Materials Availability Upon request

Code Availability Upon request

\section{Declarations}

Competing Interests The authors declare no competing interests.

Open Access This article is licensed under a Creative Commons Attribution 4.0 International License, which permits use, sharing, adaptation, distribution and reproduction in any medium or format, as long as you give appropriate credit to the original author(s) and the source, provide a link to the Creative Commons licence, and indicate if changes were made. The images or other third party material in this article are included in the article's Creative Commons licence, unless indicated otherwise in a credit line to the material. If material is not included in the article's Creative Commons licence and your intended use is not permitted by statutory regulation or exceeds the permitted use, you will need to obtain permission directly from the copyright holder. To view a copy of this licence, visit http://creativecommons.org/licenses/by/4.0/.

\section{References}

1. Ahmadjian V (1995) Lichens are more important than you think. BioScience 45(3):124. https://doi.org/10.1093/bioscience/45.3.124

2. Nash III T (2008) Lichen Biology2nd edn. Cambridge University Press, Cambridge. https://doi.org/10.1017/CBO9780511790478

3. Grube M, Cardinale M, de Castro Jr J-V, Muller H, Berg G (2009) Species-specific structural and functional diversity of bacterial communities in lichen symbioses. ISME J 3(9):1105-1115. https://doi.org/10.1038/ismej.2009.63

4. Bates ST, Cropsey GWG, Caporaso JG, Knight R, Fierer N (2011) Bacterial communities associated with the lichen symbiosis bacterial communities associated with the lichen symbiosis. Appl Environ Microbiol 77:1309-1314. https://doi.org/10.1128/AEM. 02257-10

5. Gadd GM (2007) Geomycology: biogeochemical transformations of rocks, minerals, metals and radionuclides by fungi, bioweathering and bioremediation. Mycol Res 111:3-49. https:// doi.org/10.1016/j.mycres.2006.12.001
6. Hovenden J, Seppelt RD (1995) Exposure and nutrients as delimiters of lichen communities in continental Antarctica. Lichenologist 27(6):505-516. https://doi.org/10.1016/S0024-2829(95)80010-7

7. Lindsay DC (1978) The role of lichens in Antarctic ecosystems. Bryologist 81(2):268-276. https://doi.org/10.2307/3242188

8. Critrenden PD, Kalucka I, Oliver E (1994) Does nitrogen supply limit the growth of lichens? Cryptogam Bot 4:143-155

9. Johansson O, Olofsson J, Giesler R, Palmqvist K (2011) Lichen responses to nitrogen and phosphorus additions can be explained by the different symbiont responses. New Phytol 191:795-805. https://doi.org/10.1111/j.1469-8137.2011.03739.x

10. Olech M (2004) Lichens of King George Island, Antarctica. The Institute of Botany of the Jagiellonian University, Kraków

11. Colesie C, Büdel B, Hurry V, Green TGA (2018) Can Antarctic lichens acclimatize to changes in temperature? Glob Chang Biol 24(3):1123-1135. https://doi.org/10.1111/gcb.13984

12. Sigurbjörnsdóttir M, Andrésson ÓS, Vilhelmsson O (2016) Nutrient scavenging activity and antagonistic factors of nonphotobiont lichen-associated bacteria: a review. World J Microbiol Biotechnol 32:68. https://doi.org/10.1007/s11274-0162019-2

13. Kitaura M, Scur M, Spielmann A, Lorenz-Lemke A (2018) A revision of Leptogium (Collemataceae, lichenized Ascomycota) from Antarctica with a key to species. Lichenologist 50(4):467-485. https://doi.org/10.1017/S0024282918000269

14. Rakusa-Suszczewski S (1980) Environmental conditions and the functioning of Admiralty Bay (South Shetland Islands) as part of the near shore Antarctic ecosystem. Pol Polar Res 1(1):11-27

15. Birkenmajer K (2002) Retreat of Ecology Glacier, Admiralty Bay, King George Island (South Shetland Islands, West Antarctica, 1956-2001). Bull Pol Acad Sci Earth Sci 50(1):15-29

16. Pudełko R (2003) Topographic map of the SSSI No. 8, King George Island, West Antarctica. Pol Polar Res 24(1):53-60

17. Pudełko R (2008) Two new topographic maps for sites of scientific interest on King George Island, West Antarctica. Pol Polar Res 29: 291-297

18. Weber KP, Legge RL (2009) One-dimensional metric for tracking bacterial community divergence using sole carbon source utilization patterns. J Microbiol Methods 79(1):55-61

19. Konopka A, Oliver L, Turco Jr RF (1998) The use of carbon substrate utilization patterns in environmental and ecological microbiology. Microb Ecol 35(2):103-115. https://doi.org/10.1007/ s002489900065

20. Haack SK, Garchow H, Klug MJ, Forney LJ (1995) Analysis of factors affecting the accuracy, reproducibility, and interpretation of microbial community carbon source utilization patterns. Appl Environ Microbiol 61(4):1458-1468. https://doi.org/10.1128/ AEM.61.4.1458-1468.1995

21. Stefanowicz A (2006) The biolog plates technique as a tool in ecological studies of microbial communities. Pol J Environ Stud 15(5):669-676

22. Büdel B, Rhiel E (1987) Studies on the ultrastructure of some cyanolichen haustoria. Protoplasma 139:145-152. https://doi.org/ 10.1007/BF01282285

23. Almendras K, Leiva D, Carú M, Orlando J (2018) Carbon consumption patterns of microbial communities associated with Peltigera lichens from a Chilean temperate forest. Molecules 23(11):2746. https://doi.org/10.3390/molecules23112746

24. Rikkinen J (2015) Cyanolichens. Biodivers Conserv 24:973-993. https://doi.org/10.1007/s10531-015-0906-8

25. Kong FX, Hu W, Chao SY, Sang WL, Wang LS (1999) Physiological responses of the lichen Xanthoparmelia mexicana to oxidative stress of $\mathrm{SO}_{2}$. Environ Exp Bot 42(3):201-209. https://doi.org/10.1016/S0098-8472(99)00034-9

26. Solhaug KA, Gauslaa Y (2004) Photosynthates stimulate the UV-B induced fungal anthraquinone synthesis in the foliose lichen 
Xanthoria parietina. Plant Cell Environ 27:167-176. https://oi. org/10.1111/j.1365-3040.2003.01129.x

27. Centeno DC, Hell AF, Braga MR, Del Campo EM, Casano LM (2016) Contrasting strategies used by lichen microalgae to cope with desiccation-rehydration stress revealed by metabolite profiling and cell wall analysis. Environ Microbiol 18(5):1546-1560. https:// doi.org/10.1111/1462-2920.13249

28. Grube M, Cernava T, Soh J, Fuchs S, Aschenbrenner I, Lassek C, Wegner U, Becher D, Riedel K, Sensen CW, Berg G (2015) Exploring functional contexts of symbiotic sustain within lichenassociated bacteria by comparative omics. ISME J 9(2):412-424. https://doi.org/10.1038/ismej.2014.138

29. Lee YM, Kim EH, Lee HK, Hong SG (2014) Biodiversity and physiological characteristics of Antarctic and Arctic lichensassociated bacteria. World J Microbiol Biotechnol 30(10):27112721. https://doi.org/10.1007/s11274-014-1695-Z

30. Kono M, Tanabe H, Ohmura Y, Satta Y, Terai Y (2017) Physical contact and carbon transfer between a lichen-forming Trebouxia alga and a novel Alphaproteobacterium. Microbiology 163(5): 678-691. https://doi.org/10.1099/mic.0.000461

31. Alam MA, Gauslaa Y, Solhaug KA (2015) Soluble carbohydrates and relative growth rates in chloro-, cyano- and cephalolichens: effects of temperature and nocturnal hydration. New Phytol 208: 750-762. https://doi.org/10.1111/nph.13484

32. Giełwanowska I, Olech M (2012) New ultrastructural and physiological features of the thallus in Antarctic lichens. Acta Biol Cracov Ser Bot 54(1):40-52

33. Zdanowski MK, Żmuda-Baranowska MJ, Borsuk P, Światecki A, Górniak D, Wolicka D, Jankowska KM, Grzesiak J (2013) Culturable bacteria community development in postglacial soils of Ecology Glacier, King George Island, Antarctica. Polar Biol 36: 511-527. https://doi.org/10.1007/s00300-012-1278-0

34. Lechowicz MJ (1983) Age dependence of photosynthesis in the caribou lichen Cladina stellaris. Plant Physiol 71(4):893-895. https://doi.org/10.1104/pp.71.4.893

35. Armstrong RA, Bradwell T (2011) Growth of foliose lichens: a review. Symbiosis 53:1-16. https://doi.org/10.1007/s13199-0110108-4

36. Honegger R (1993) Developmental biology of lichens. New Phytol 125:659-677. https://doi.org/10.1111/j.1469-8137.1993.tb03916.x

37. Ramanan R, Kim BH, Cho DH, Oh HM, Kim HS (2016) Algaebacteria interactions: evolution, ecology and emerging applications. Biotechnol Adv 34(1):14-29. https://doi.org/10.1016/j.biotechadv. 2015.12.003

38. Brzeszcz J, Steliga T, Kapusta P, Turkiewicz A, Kaszycki P (2016) $\mathrm{R}$-strategist versus $\mathrm{K}$-strategist for the application in bioremediation of hydrocarbon-contaminated soils. Int Biodeterior Biodegradation 106:41-52

39. Breen K, Levesque E (2006) Proglacial succession of biological soil crusts and vascular plants: biotic interactions in the High Arctic. Can J Bot 84(11):1714-1731. https://doi.org/10.1139/b06-131

40. Oksanen I (2006) Ecological and biotechnological aspects of lichens. Appl Microbiol Biotechnol 73:723-734. https://doi.org/10. 1007/s00253-006-0611-3

41. Hodkinson BP, Lutzoni F (2009) A microbiotic survey of lichenassociated bacteria reveals a new lineage from the Rhizobiales. Symbiosis 49:163-180. https://doi.org/10.1007/s13199-009-0049-3

42. Kumar RS, Thajuddin N, Venkateswari C (2010) Antibacterial activity of cyanolichen and symbiotic cyanobacteria against some selected microorganisms. Afr J Microbiol Res 4(13):1408-1411. https://doi.org/10.5897/AJMR.9000049

43. Grzesiak J, Kaczyńska A, Gawor J, Żuchniewicz K, AleksandrzakPiekarczyk T, Gromadka R, Zdanowski MK (2020) A smelly business: microbiology of Adélie penguin guano (Point Thomas rookery, Antarctica). Sci Total Environ 714:136714. https://doi.org/10. 1016/j.scitotenv.2020.136714

44. Dahlman L, Persson J, Näsholm T, Palmqvist K (2003) Carbon and nitrogen distribution in the green algal lichens Hypogymnia physodes and Platismatia glauca in relation to nutrient supply. Planta 217(1):41-48

45. Wiskich JT (1980) Control of the Krebs cycle. In: Davies DD (ed) The Biochemistry of Plants. Metabolism and Respiration, vol 2. Academic Press, New York, pp 243-278

46. Ilyas S, Chi RA, Lee JC (2013) Fungal bioleaching of metals from mine tailing. Miner Process Ext Metall 34(3):185-194. https://doi. org $/ 10.1080 / 08827508.2011 .623751$

47. Vitousek PM, Porder S, Houlton BZ, Chadwick OA (2010) Terrestrial phosphorus limitation: mechanisms, implications, and nitrogen-phosphorus interactions. Ecol Appl 20(1):5-15

48. Unden G, Strecker A, Kleefeld A, Kim OB (2016) C4Dicarboxylate utilization in aerobic and anaerobic growth. EcoSal Plus 7(1). https://doi.org/10.1128/ecosalplus.ESP-0021-2015

49. Smith RL (1995) Colonization by lichens and the development of lichen-dominated communities in the maritime Antarctic. Lichenologist 27(6):473-483. https://doi.org/10.1016/S00242829(95)80007-7

50. Asplund J, Wardle DA (2017) How lichens impact on terrestrial community and ecosystem properties. Biol Rev 92:1720-1738. https://doi.org/10.1111/brv.12305

51. Lawrey JD (1995) Lichen allelopathy: a review. In: Inderjit DKMM, Einhellig FA (eds) Allelopathy: Organisms, processes, and applications. American Chemical Society, Washington, DC, pp 26-38 